\title{
Isotherm, kinetic and thermodynamic studies for the adsorption of methylene blue on almond leaf powder
}

\author{
Adnan ALDEMIR ${ }^{1, *}$ Ali Riza KUL ${ }^{2}$ \\ ${ }^{1}$ Van Yüzüncü Yıl University, Faculty of Engineering, Chemical Engineering Department, 65080, Van \\ ${ }^{2}$ Van Yüzüncü Yıl University, Faculty of Science, Chemistry Department, 65080, Van
}

\begin{abstract}
In this study almond leaf powder (ALP) was used as an adsorbent for the methylene blue (MB) removal. The initial $\mathrm{MB}$ concentration, interaction time and temperature effects were investigated in a batch experimental system. The equilibrium data was modelled using Langmuir, Freundlich and Temkin adsorption isotherms, while kinetic parameters were determined using the pseudo first order (PFO), pseudo second order (PSO) and intra-particle diffusion (IPD) models. It was noted that the Freundlich model was the most convenient option compared to the Langmuir and Temkin models. The Freundlich model coefficients increased as the temperature increased, proving that adsorption process is favorable at higher temperatures. The results also indicated that the experimental and calculated $\mathrm{q}_{\mathrm{e}}$ values were close to each other, which shows that this process fits the PSO kinetic model with higher $\mathrm{R}^{2}$ values than other two models. Kinetic constants became closer to both temperatures and the initial concentrations and $\mathrm{q}_{\mathrm{e}}$ values increased with the increase in the concentration of MB. The initial MB concentration increased from 10 to $60 \mathrm{mg} / \mathrm{L}$, while the adsorption capacity on ALP increased from 1.46 to $9.24 \mathrm{mg} / \mathrm{g}, 1.61$ to $9.71 \mathrm{mg} / \mathrm{g}$ and 1.89 to $10.71 \mathrm{mg} / \mathrm{g}$ for 298,308 and $323 \mathrm{~K}$, respectively. Gibbs free energy, enthalpy and entropy of this separation process were determined as $-1737.1 \mathrm{~J} / \mathrm{mol}, 14.776 \mathrm{~kJ} / \mathrm{mol}$ and $55.413 \mathrm{~J} / \mathrm{mol}$, respectively. Results of this study showed that ALP can be an alternative material for dye removal.
\end{abstract}

\section{Article info \\ History:}

Received:15.04.2020

Accepted:02.07.2020

Keywords:

Almond leaf powder,

Dye adsorption,

Methylene blue,

Isotherm model,

Kinetic coefficient,

Thermodynamic

parameters

\section{Introduction}

Removing hazardous compounds from wastewater are one of the most serious environmental challenges faced by humans today [1]. This matter has received considerable attention due to the fact that most organic dyestuffs are hazardous to humans, animals and other organisms [2]. Dyes are generally utilized to impart color in different industries [3]. Commercial dyes can be classified in several ways including chemical structure, color and application methods. They are generally classified as cationic, anionic and non-ionic. The different classes of dyes and their effects are given in [4-7]. Dyes have stable and complex structures and low biodegradability. They are toxic to organisms living in waters and prejudicial to photosynthetic activities and some dyes have harmful effects in humans. Owing to their harmful effects, removals of dyes from aqueous solutions have been studied extensively by researchers [8-9].
A variety of chemical and biological treatment technologies are applied to wastewaters [10-12]. Among these is the adsorption technique which is relatively economical, flexible, efficient, has a simple design and has been proved to be an effective technique in treating colorized wastewaters [13]. The performance of adsorption is related to the adsorbent materials. Activated carbon, which is commonly used adsorbent, has high operational costs and after it has been used the water is required to be regenerated [14]. This limitation has encouraged the search for different adsorbents, such as natural materials, biosorbents and waste materials from industrial or agricultural processes. Natural wastes have been favored as adsorbents due to being low in cost, high in efficiency, non-hazardous to nature and locally available materials $[15,16]$.

There are many studies in the literature that have used various agri-food materials, such as peanut hulls, pineapple stems, garlic peels, rice, wheat and coffee husks, banana and orange peels and peach gum, for the depollution of aqueous solutions [16-18]. However, 
the need to find new materials that easily available, low-cost and environmentally friendly are still existing. Consequently, various kinds of leaves have been utilized as bioadsorbents in the dyes removal applications for removal of dyes from wastewaters [19].

MB has been continually investigated by researchers and has used for adsorption studies regarding organic contaminants in aqueous solutions [20]. MB has a wide application area such as cotton and wool dyes, paper stock coating and analytical reagents. Although not exactly poisonous, $\mathrm{MB}$ can have damaging effects on humans and animals [21,22]. Thus, Removal of BM from aqueous solutions is extremely important. Various leaf-based adsorbents were investigated for MB adsorption and some of them provided well-suited [23-27].

The interference among the adsorbent and adsorbate molecules is explained with adsorption isotherms. The nature of the adsorbate can change the amount that can be adsorbed, the adsorbent affect and the adsorption isotherm profile shape. The different isotherms were used to investigate the results [28]. According to the Langmuir isotherm, adsorption of the monolayer and all active sites on the surface of the adsorbent are equal in energy. The Freundlich isotherm clarifies the multilayer adsorption behavior, while the Temkin isotherm describes the interaction of solute molecules in the aqueous phases with heterogeneous solid surfaces [29]. The effect of temperature on adsorption was determined by analyzing thermodynamic parameters including Gibbs free energy $(\Delta \mathrm{G})$, entropy $(\Delta \mathrm{S})$ and enthalpy $(\Delta \mathrm{H})$. The kinetic mechanism of adsorption was explained using calculated different equations including PFO, PSO and IPD models [30].

The purpose of this study is investigated the adsorption capacity of ALP for MB which is selected as the adsorbate on account of the fact that it is a commonly used dye. Adsorption techniques were suggested by examining the isotherms, kinetics and thermodynamic of MB adsorption on ALP.

\section{Materials and Methods}

\subsection{Adsorbent}

ALP, used in adsorption experiments, was made from leaves of the almond trees (Prunus dulcis) growing on the Akdamar Island located in Van Lake, Turkey. The collected almond leaves were washed with deionized water to remove impurities and were dried at $90{ }^{\circ} \mathrm{C}$ in an oven for $24 \mathrm{~h}$. The scales of almond leaves were reduced and blended in food processor. The emergent powder was sieved and particles below $150 \mu \mathrm{m}$ were collected.

\subsection{Adsorbate}

In this study, $\mathrm{MB}$, a cationic dye, was used as the adsorbate which formula is $\mathrm{C}_{6} \mathrm{H}_{18} \mathrm{~N}_{3} \mathrm{SCl} .3 \mathrm{H}_{2} \mathrm{O}$ and the molecular weight is $319.85 \mathrm{~g} / \mathrm{mol}$. MB was purchased from Merck Chemicals Company and stock dye solution was prepared for experiments.

\subsection{Adsorption experiments}

Within the scope of batch experiments, which were carried out in a temperature-controlled water bath, $2 \mathrm{~g}$ ALP was treated with $500 \mathrm{~mL}$ of $\mathrm{MB}$ solution. Different MB concentrations (10, 20, 30, 40, 50, 60 $\mathrm{mg} / \mathrm{L}$ ) in the solution of MB determined for $200 \mathrm{~min}$ while the $\mathrm{pH}$ was gradually adjusted by adding either $\mathrm{H}_{2} \mathrm{SO}_{4}$ or $\mathrm{NaOH}$ solutions $(0.1 \mathrm{M})$. All of the experiments were carried out in triplicate at the same conditions at temperatures of $298 \mathrm{~K}, 308 \mathrm{~K}$ and $323 \mathrm{~K}$ and the average values were taken to represent the results when calculating the overall data. For UV/VIS spectrophotometer (PG Instruments Ltd. T80 model) a calibration curve was obtained by plotting among absorbance and certain concentrations of the dye solution at a maximum $660 \mathrm{~nm}$ wavelenght. This calibration curve was used to measure unknown MB concentration. The dye adsorption capacity of adsorbent was analyzed using the equation given below:

$q_{e}=\left(C_{0}-C_{e}\right) V / m$

where $\mathrm{V}$ was the solution volume $(\mathrm{L}), \mathrm{C}_{0}$ and $\mathrm{C}_{\mathrm{e}}$ were initial and equilibrium concentration of the dye $(\mathrm{mg} / \mathrm{L})$ and $\mathrm{W}$ was adsorbent mass (g). Data obtained from batch experiments were used in isotherm, kinetic and thermodynamic calculations to design the MB removal with ALP.

\section{Results and Discussion}

\subsection{Adsorption isotherm studies}

Many different models are used to identify the adsorption of dyes on solid surfaces. In this research three isotherm models, Freundlich, Langmuir and Temkin, where selected to investigate the interactions between dye and adsorbent. These models were applicable for the descriptions of the experimental results obtained at three different temperatures. The parameters of these isotherm models were calculated using linear form of their equations [31]. The amount of MB adsorbed per unit by samples $\left(\mathrm{q}_{\mathrm{e}}\right)$ and equilibrium concentrations $\left(\mathrm{C}_{\mathrm{e}}\right)$ for three temperatures are given in Figure 1. It was determined that adsorption 
efficiency increased with the increase in initial MB concentration.

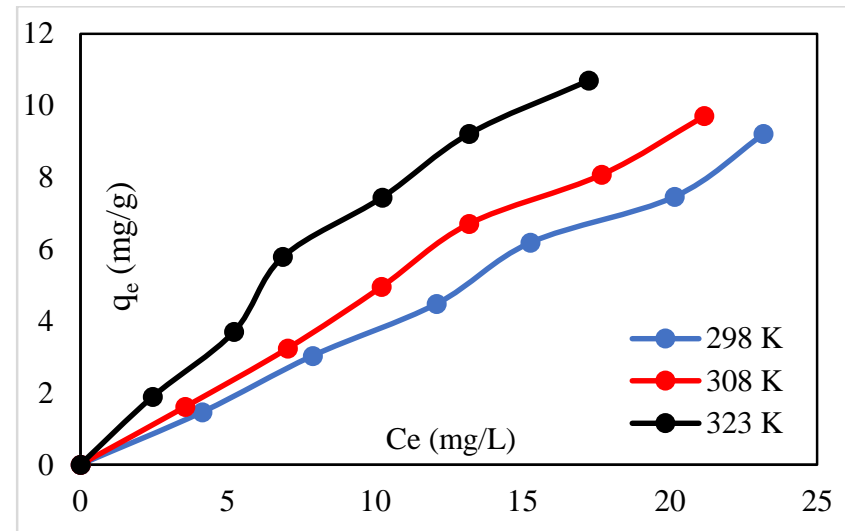

Figure 1. Adsorption isotherms of MB on ALP for different temperatures

The Langmuir isotherm model has some assumptions for the adsorption occurrence on a homogenous surface without interaction between adsorbates in the plane of the surface. Langmuir isotherm model is given Eq. (2);

$q_{e}=\left(q_{m} K_{L} C_{e}\right) /\left(1+K_{L} C_{e}\right)$

where $\mathrm{q}_{\mathrm{m}}$ is maximum capacity of adsorption $(\mathrm{mg} / \mathrm{g})$, $\mathrm{K}_{\mathrm{L}}$ is Langmuir constant $(\mathrm{L} / \mathrm{g}) . \mathrm{q}_{\mathrm{m}}$ and $\mathrm{K}_{\mathrm{L}}$ values were determined from plot of the $\mathrm{C}_{\mathrm{e}} / \mathrm{q}_{\mathrm{e}}$ versus $\mathrm{C}_{\mathrm{e}}$, respectively. Langmuir isotherm results for $\mathrm{MB}$ adsorption on ALP at 298, 308, 323K are given in Figure 2.

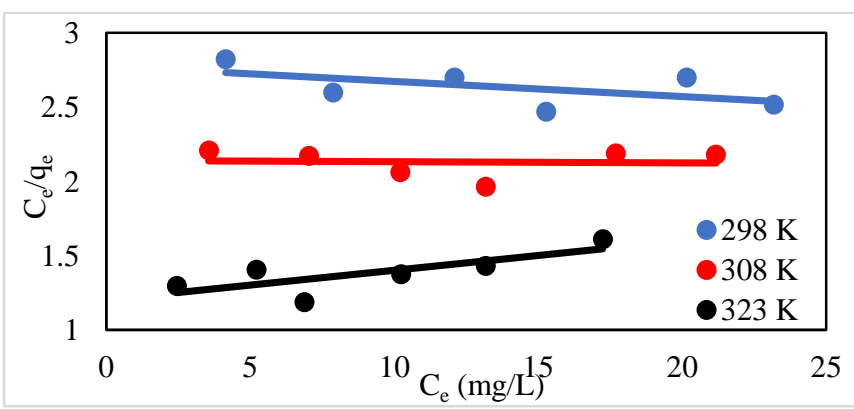

Figure 2. Langmuir isotherms of MB adsorption on ALP at different temperatures

The Freundlich isotherm model is based on adsorption on heterogeneous surfaces. Freundlich isotherm model is given Eq. (3);

$q_{e}=K_{F} C_{e}^{1 / n}$

where $\mathrm{K}_{\mathrm{F}}$ is a Freundlich constant $(\mathrm{L} / \mathrm{g}), 1 / \mathrm{n}$ is an empirical parameter. $\mathrm{K}_{\mathrm{F}}$ and $\mathrm{n}$ values were found from intercept and slope of the plot between $\operatorname{lnq}_{\mathrm{e}}$ against $\ln C_{e}$, respectively. The Freundlich isotherm results for MB adsorption on ALP at 298, 308 and $323 \mathrm{~K}$ are given in Figure 3.

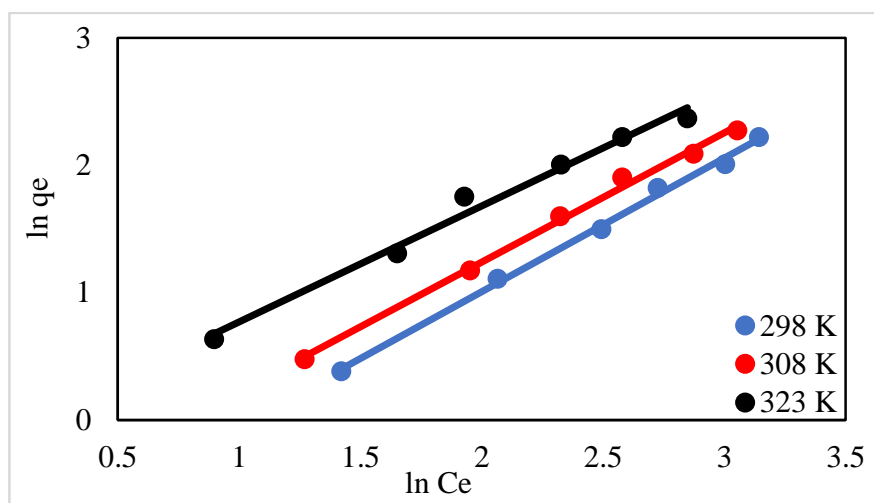

Figure 3. Freundlich isotherms of MB adsorption on ALP at different temperatures

The Temkin isotherm model describes interactions of solute molecules on solid surfaces. This isotherm is based on the concept that heat of adsorption decreases when the solid surface is covered. Temkin isotherm model is given with Eq. (4);

$q_{e}=B \ln \left(K_{T} C_{e}\right)$

where $\mathrm{K}_{\mathrm{T}}$ and $\mathrm{B}$ constants are evaluated from the plot. B illustrates constant related to heat of adsorption, which is calculated with Eq. (5);

$B=R T / b_{T}$

where $1 / b_{\mathrm{T}}$ symbolizes adsorption potential; $\mathrm{R}$ means gas constant $(8.314 \mathrm{~J} / \mathrm{kmol})$; and $\mathrm{T}$ is temperature in Kelvin (K). Temkin isotherm results for MB adsorption on ALP at 298, 308 and $323 \mathrm{~K}$ are given in Figure 4.

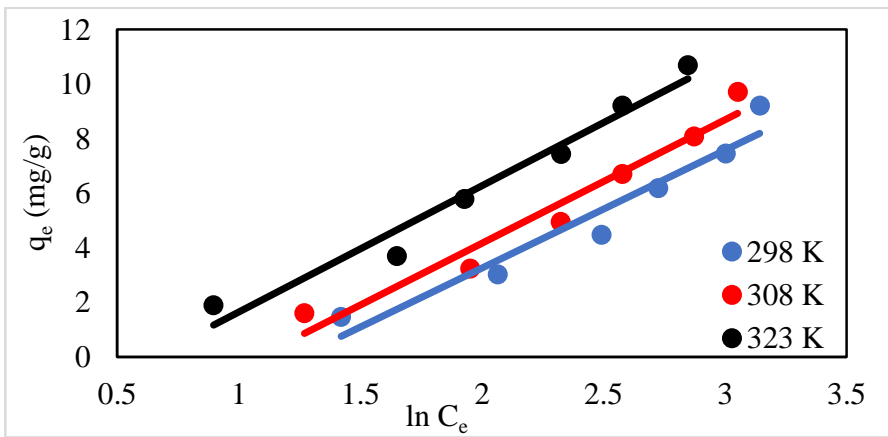

Figure 4. Temkin isotherms of MB adsorption on ALP at different temperatures

The calculated parameters of Langmuir, Freundlich and Temkin isotherms are shown in Table 1. Freundlich model was more fitting compared to the other two models with regards to the determined coefficients. The values of $K_{F}$ and $n$ were increased when the temperature increase and adsorption was also 
increased with the higher temperatures. The $\mathrm{R}^{2}$ values of the three isotherm models were high, however the $\mathrm{R}^{2}$ values of the Freundlich model were higher than other two models. The $\mathrm{q}_{\mathrm{m}}$ values of adsorbents produced from different leaves for MB removal calculated using the Langmuir isotherm model are given in Table 2 and different adsorbents used for MB removal including agricultural and industrial wastes are given in [32].

Table 1. Isotherm model parameters of MG adsorption on ALP at different temperatures

\begin{tabular}{cccccccccc}
\hline Temp & \multicolumn{3}{c}{ Langmuir } & \multicolumn{3}{c}{ Freundlich } & \multicolumn{3}{c}{ Temkin } \\
\hline $\mathrm{K}$ & $\begin{array}{c}\mathrm{K}_{\mathrm{L}} \\
(\mathrm{L} / \mathrm{g})\end{array}$ & $\begin{array}{c}\mathrm{q}_{\mathrm{m}} \\
(\mathrm{mg} / \mathrm{g})\end{array}$ & $\mathrm{R}^{2}$ & $\mathrm{n}$ & $\begin{array}{c}\mathrm{K}_{\mathrm{F}} \\
(\mathrm{L} / \mathrm{g})\end{array}$ & $\mathrm{R}^{2}$ & $\begin{array}{c}\mathrm{K}_{\mathrm{T}} \\
(\mathrm{L} / \mathrm{g})\end{array}$ & $\begin{array}{c}\mathrm{b}_{\mathrm{T}} \\
(\mathrm{J} / \mathrm{mol})\end{array}$ & $\mathrm{R}^{2}$ \\
\hline 298 & 0.0165 & 50.251 & 0.3099 & 0.9534 & 0.3394 & 0.9967 & 0.6231 & 898.517 & 0.8519 \\
\hline 308 & 0.0253 & 98.039 & 0.2869 & 0.9841 & 0.4522 & 0.9955 & 0.6545 & 814.228 & 0.8847 \\
\hline 323 & 0.0374 & 125.013 & 0.5833 & 1.0978 & 0.8697 & 0.9947 & 0.7561 & 712.541 & 0.8447 \\
\hline
\end{tabular}

Table 2. Adsorption capacity of different leaf powders on MB

\begin{tabular}{ccc}
\hline Adsorbent & $\mathrm{q}_{\mathrm{m}}(\mathrm{mg} / \mathrm{g})$ & References \\
\hline Plane leaves powder & 114.9 & {$[1]$} \\
Lotus leaves powder & 221.7 & {$[24]$} \\
Date palm leaves powder & 58.1 & {$[25]$} \\
Oil palm leaves powder & 103.2 & {$[26]$} \\
Neem leaves powder & 19.6 & {$[27]$} \\
Weeping pillow leaves powder & 60.9 & {$[30]$} \\
Gulmohar leaves powder & 186.2 & {$[33]$} \\
Almond leaves powder & 125.0 & This study \\
\hline
\end{tabular}

\subsection{Temperature and adsorption thermodynamics}

The temperature effect on MB adsorption was determined by carrying out the same experiments at three different temperatures. The results of the experiments indicated that dye adsorption capacity decreased with the rise in temperature. A thermodynamic investigation was conducted to determine the significance of the adsorption process. $\Delta \mathrm{G}^{\circ}, \Delta \mathrm{H}^{\circ}$ and $\Delta \mathrm{S}^{\circ}$ parameters were used for detecting any heat alterations in the adsorption process regarding MB and ALP [11]. These parameters were calculated with Eq. (6) - (9);

$K_{c}=C_{A d s} / C_{e}$

$\Delta G^{\circ}=-R T \ln K_{C}$

$\Delta G^{\circ}=\Delta H^{\circ}-\left(T \Delta S^{\circ}\right)$

$\ln K_{C}=\left(\Delta S^{\circ} / R\right)-\left(\Delta H^{\circ} /(R T)\right)$

where, $\mathrm{K}_{\mathrm{C}}$ is equilibrium constant, $\mathrm{C}_{\mathrm{Ads}}$ is dye amount (mg) adsorbed by ALP per liter of the solution at equilibrium, the adsorbent of adsorbent per unit litter of solution. The $\Delta \mathrm{H}^{\circ}$ and $\Delta \mathrm{S}^{\circ}$ parameters were analyzed from slope and intercept of the $\operatorname{lnKc}$ versus $1 / \mathrm{T}$ plot. From the graphical representation, according to Eq. (9), namely $\operatorname{lnKc} v \mathrm{vs} 1 / \mathrm{T}$, a straight line is obtained in Figure 5 and thermodynamic parameters were illustrated in Table 3. The thermodynamic parameters of MB adsorption on ALP were calculated with using Equations 6-9. The $\Delta \mathrm{G}^{\circ}$ values for $\mathrm{MB}$ on ALP were obtained as $-1.7371,-2.2912$ and -3.1224 $\mathrm{kJ} / \mathrm{mol}$ for $298 \mathrm{~K}, 308 \mathrm{~K}$ and $323 \mathrm{~K}$, respectively. The $\Delta \mathrm{H}^{\circ}$ and $\Delta \mathrm{S}^{\circ}$ values of MB adsorption on ALP were determined as $14.776 \mathrm{~kJ} / \mathrm{mol}$ and $55.413 \mathrm{~kJ} / \mathrm{mol} . \mathrm{K}$, respectively. $\Delta \mathrm{G}^{\circ}$ values showed feasibility and spontaneous nature of adsorption, while negative $\Delta \mathrm{G}^{\circ}$ values indicated that adsorption was physisorption. The decrease in absolute values of $\Delta \mathrm{G}^{\circ}$ with the increase in temperature shows that this separation process is constructive at low temperatures. The positive $\Delta \mathrm{H}^{\circ}$ value is showed that process is endothermic and the positive $\Delta \mathrm{S}^{\circ}$ value is verified the affinity of ALP on MB.

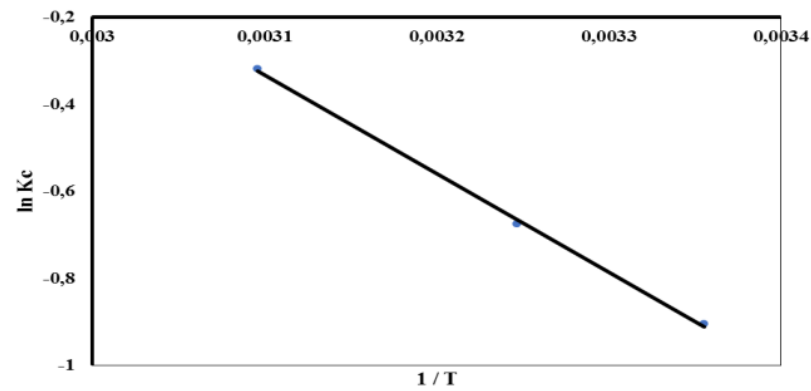

Figure 5. $\operatorname{lnKc}$ versus $1 / \mathrm{T}$ plot for $\mathrm{MB}$ adsorption on ALP 
Table 3. Thermodynamic parameters of MB adsorption on ALP

\begin{tabular}{ccccc}
\hline Temp $(\mathrm{K})$ & $\begin{array}{c}\Delta \mathrm{G}^{\circ} \\
(\mathrm{kJ} / \mathrm{mol})\end{array}$ & $\begin{array}{c}\Delta \mathrm{H}^{\circ} \\
(\mathrm{kJ} / \mathrm{mol})\end{array}$ & $\begin{array}{c}\Delta \mathrm{S}^{\circ} \\
(\mathrm{J} / \mathrm{mol} . \mathrm{K})\end{array}$ & $\mathrm{R}^{2}$ \\
\hline 298 & -1.7371 & & & \\
308 & -2.2912 & 14.776 & 55.413 & 0.999 \\
323 & -3.1224 & & & \\
\hline
\end{tabular}

\subsection{Effect of initial concentrations and contact time on adsorption}

Time is one of the most significant factors used in planning and operating of treatment. In Figures 6-8, MB removal from the solutions is extremely fast at the initial period, while the velocity in final period reaches of balance decreases. The equilibrium time in dye adsorption was found as $120 \mathrm{~min}$ for MB removal from the solutions. Figures 6-8 show that increase in initial concentration of $\mathrm{MB}$ caused an increment in the adsorption capacity for all three temperatures. As the initial MB concentration increased from 10 to $60 \mathrm{mg} / \mathrm{L}$, capacity of MB adsorption on ALP increased from 1.46 to $9.24 \mathrm{mg} / \mathrm{g}, 1.61$ to $9.71 \mathrm{mg} / \mathrm{g}$ and 1.89 to 10.71 $\mathrm{mg} / \mathrm{g}$ for $298 \mathrm{~K}, 308 \mathrm{~K}$ and $323 \mathrm{~K}$, respectively. This data shows that initial concentration plays a critical role in adsorption capacity, which provides a driving force for the adsorption. According to the experimental results, the maximum dye adsorption rate was obtained with $60 \mathrm{mg} / \mathrm{L}$ initial dye concentration. In the present study, MB adsorption on ALP has similarity. When the results of the present study were compared to those in the literature, it was determined that dye adsorption capacity of ALP is good and it may be a novel material used as an inexpensive adsorbent for dye removal.

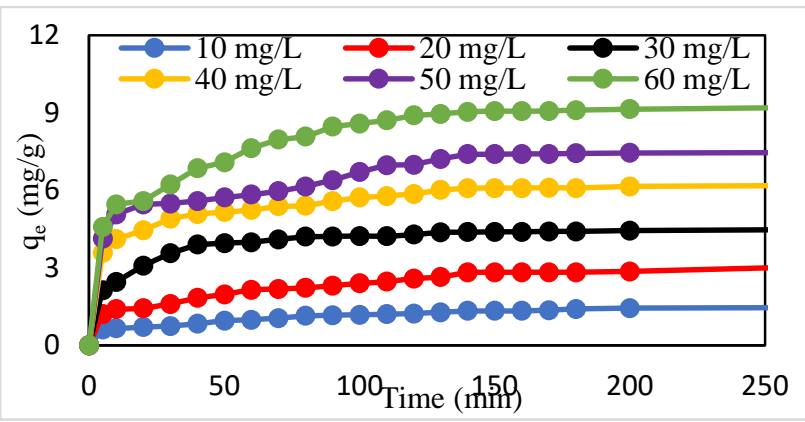

Figure 6. Effect of time and concentration of MB removal with ALP at $298 \mathrm{~K}$

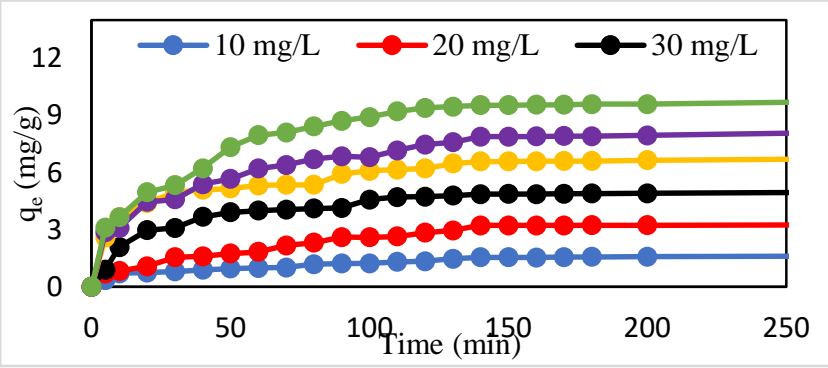

Figure 7. Effect of time and concentration of MB removal with ALP at $308 \mathrm{~K}$

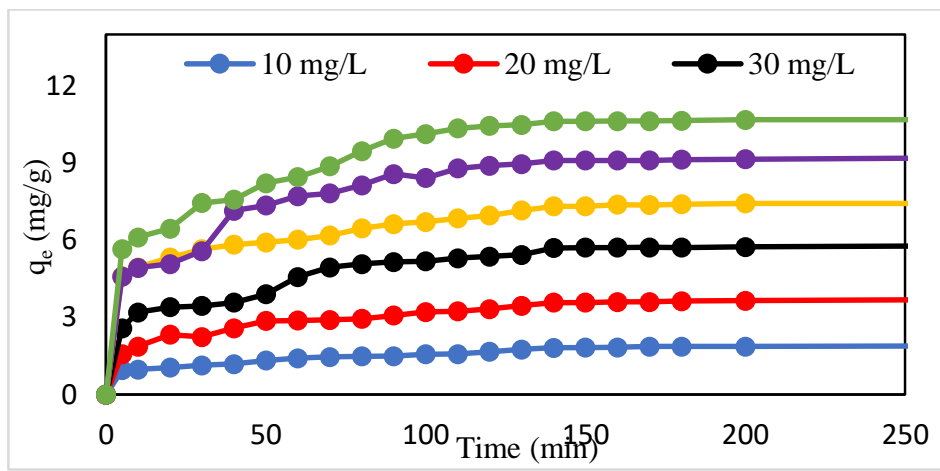

Figure 8. Effect of time and concentration of MB removal with ALP at $323 \mathrm{~K}$

\subsection{Adsorption kinetics studies}

Kinetic models were applied to check the experimental results of adsorbates adsorption on adsorbents. Adsorption kinetics of dyes is important when choosing the best test circumstances for the separation process [33]. In the present study, the kinetics of MB were calculated by using PFO, PSO and IPD models. The best-suited model was chosen depending on the $\mathrm{R}^{2}$ coefficient values. The models were examined according to the experimental data at varied temperatures and initial $\mathrm{MB}$ concentrations.

PFO kinetic model can be the first for the characterization of liquid-solid adsorption systems depending on solid capacity [33]. PFO kinetic model is given with Eq. (10);

$\ln \left(q_{e}-q_{t}\right)=\ln q_{e}-k_{1} t$

where $\mathrm{q}_{\mathrm{e}}$ and $\mathrm{q}_{\mathrm{t}}(\mathrm{mg} / \mathrm{g})$ values are the adsorption capacities at equilibrium and at time, respectively, and $\mathrm{k}_{1}\left(\mathrm{~min}^{-1}\right)$ is the rate constant. PFO constants were determined from slope and intercept of the plot which prepared the $\ln \left(\mathrm{q}_{\mathrm{e}}-\mathrm{q}_{\mathrm{t}}\right)$ against $\mathrm{t}$ values.

The PSO kinetic model, which can be explained with the chemical bond formation between the adsorptive site and solute molecule, is a rate-limiting step based on adsorption capacity. The equation for the PSO model is given with Eq. (11);

$t / q_{t}=1 /\left(k_{2} q_{e}^{2}\right)+\left(t / q_{e}\right)$

where $\mathrm{k}_{2}$ is the rate of adsorption $(\mathrm{g} / \mathrm{mg} \mathrm{min}), \mathrm{q}_{\mathrm{e}}$ is the amount of adsorbate that adsorbed on the adsorbent at 
equilibrium ( $\mathrm{mg} / \mathrm{g}$ ) and $\mathrm{q}_{\mathrm{t}}$ is the amount of dye adsorbed at any time $(\mathrm{mg} / \mathrm{g}) . \mathrm{k}_{2}$ and $\mathrm{q}_{\mathrm{e}}$ values were determined from intercept and slope of the plot of $t / q_{t}$ vs $t$, respectively.

IPD model was used as the rate controlling step, it was determined that the adsorption of the dyes was more gradual. According to this model the chemical or physical bond designed between solute. The equation for this model was suggested by Weber and Morris and was created by testing possibility of IPD as a rate limiting step. The IPD kinetic model is given with Eq. (12);

$q_{t}=k_{i p d} t^{0.5}+C$

where $\mathrm{k}_{\mathrm{ipd}}\left(\mathrm{mg} / \mathrm{g} \mathrm{min}^{1 / 2}\right)$ is the IPD constant and $\mathrm{C}$ gives an idea on the boundary thickness. A plot of $\mathrm{q}_{\mathrm{t}}$ against $\mathrm{t}^{0.5}$ at different $\mathrm{MB}$ concentrations gave two phases of linear plots [33].
PFO, PSO and IPD kinetic parameters are given in Table 4. Experimental results showed that $\mathrm{R}^{2}$ coefficients of PSO were higher than 0.99 with the experimental and analyzed qe values were very close to each other. This determined that the process best fit the PSO kinetic model. Moreover, for most dye adsorption systems kinetic data are most often better represented by PSO model. Experimental and calculated $\mathrm{q}_{\mathrm{e}}$ values of $323 \mathrm{~K}$ were higher than the 298 $\mathrm{K}$ and $308 \mathrm{~K}$ values. Accordingly, it can be said that the $\mathrm{q}_{\mathrm{e}}$ values increased with the increase in concentration of MB. When kinetic constants were compared, it was seen that the constant values were closer to both temperatures and concentrations of the PSO model [33]. This result showed that $\mathrm{MG}$ adsorption kinetics on ALP result from the PSO model and that the step of rate-limiting can be the dye chemisorption.

Table 4. PFO, PSO and IPD kinetic parameters of MB adsorption on ALP

\begin{tabular}{|c|c|c|c|c|c|c|c|c|}
\hline $\begin{array}{l}\text { Kinetic } \\
\text { Model }\end{array}$ & $\begin{array}{l}\text { Temp } \\
(\mathrm{K})\end{array}$ & $\begin{array}{c}\text { Kinetic } \\
\text { Coefficients }\end{array}$ & $\begin{array}{c}10 \\
(\mathrm{mg} / \mathrm{L})\end{array}$ & $\begin{array}{c}20 \\
(\mathrm{mg} / \mathrm{L})\end{array}$ & $\begin{array}{c}30 \\
(\mathrm{mg} / \mathrm{L})\end{array}$ & $\begin{array}{c}40 \\
(\mathrm{mg} / \mathrm{L})\end{array}$ & $\begin{array}{c}50 \\
(\mathrm{mg} / \mathrm{L})\end{array}$ & $\begin{array}{c}60 \\
(\mathrm{mg} / \mathrm{L})\end{array}$ \\
\hline & 298 & $\mathrm{q}_{\mathrm{e} \exp }(\mathrm{mg} / \mathrm{g})$ & 1.465 & 3.032 & 4.478 & 6.183 & 7.468 & 9.205 \\
\hline & 308 & $\mathrm{q}_{\mathrm{e} \exp }(\mathrm{mg} / \mathrm{g})$ & 1.613 & 3.245 & 4.948 & 6.705 & 8.078 & 9.708 \\
\hline & 323 & $\mathrm{q}_{\mathrm{e} \exp }(\mathrm{mg} / \mathrm{g})$ & 1.888 & 3.698 & 5.783 & 7.445 & 9.205 & 10.693 \\
\hline \multirow{9}{*}{$\begin{array}{c}\text { PFO } \\
\text { kinetic } \\
\text { model }\end{array}$} & \multirow{3}{*}{298} & $\mathrm{k}_{1}\left(\min ^{-1}\right)$ & 0.0152 & 0.0137 & 0.0206 & 0.0219 & 0.0283 & 0.0235 \\
\hline & & $\mathrm{q}_{\mathrm{e} \text { cal }}(\mathrm{mg} / \mathrm{g})$ & 1.138 & 1.987 & 2.143 & 3.353 & 5.509 & 6.102 \\
\hline & & $\mathrm{R}^{2}$ & 0.9483 & 0.9567 & 0.9467 & 0.9577 & 0.9153 & 0.9857 \\
\hline & \multirow{3}{*}{308} & $\mathrm{k}_{1}\left(\min ^{-1}\right)$ & 0.0192 & 0.0228 & 0.0241 & 0.0219 & 0.0209 & 0.0238 \\
\hline & & $\mathrm{q}_{\mathrm{e} \text { cal }}(\mathrm{mg} / \mathrm{g})$ & 1.651 & 3.159 & 4.033 & 4.761 & 6.736 & 7.844 \\
\hline & & $\mathrm{R}^{2}$ & 0.9431 & 0.8729 & 0.9734 & 0.9621 & 0.9668 & 0.9754 \\
\hline & \multirow{3}{*}{323} & $\mathrm{k}_{1}\left(\min ^{-1}\right)$ & 0.0235 & 0.0204 & 0.0251 & 0.0232 & 0.0258 & 0.0326 \\
\hline & & $\mathrm{q}_{\mathrm{e} \text { cal }}(\mathrm{mg} / \mathrm{g})$ & 1.845 & 2.844 & 5.023 & 5.441 & 6.821 & 10.477 \\
\hline & & $\mathrm{R}^{2}$ & 0.9122 & 0.9621 & 0.9509 & 0.9461 & 0.9781 & 0.9661 \\
\hline \multirow{9}{*}{$\begin{array}{c}\text { PSO } \\
\text { kinetic } \\
\text { model }\end{array}$} & \multirow{3}{*}{298} & $\mathrm{k}_{2}\left(\min ^{-1}\right)$ & 0.0268 & 0.0236 & 0.0213 & 0.0185 & 0.0106 & 0.0091 \\
\hline & & $\mathrm{q}_{\mathrm{e} \mathrm{cal}}(\mathrm{mg} / \mathrm{g})$ & 1.547 & 3.168 & 4.585 & 6.349 & 7.800 & 9.634 \\
\hline & & $\mathrm{R}^{2}$ & 0.9933 & 0.9938 & 0.9992 & 0.9978 & 0.9931 & 0.9967 \\
\hline & \multirow{3}{*}{308} & $\mathrm{k}_{2}\left(\min ^{-1}\right)$ & 0.0176 & 0.0162 & 0.0129 & 0.0108 & 0.0062 & 0.0054 \\
\hline & & $\mathrm{q}_{\mathrm{e} \text { cal }}(\mathrm{mg} / \mathrm{g})$ & 1.787 & 3.852 & 5.322 & 7.018 & 8.658 & 10.482 \\
\hline & & $\mathrm{R}^{2}$ & 0.9962 & 0.9985 & 0.9944 & 0.9946 & 0.9919 & 0.9934 \\
\hline & \multirow{3}{*}{323} & $\mathrm{k}_{2}\left(\min ^{-1}\right)$ & 0.0261 & 0.0161 & 0.0101 & 0.0126 & 0.0083 & 0.0073 \\
\hline & & $\mathrm{q}_{\mathrm{e} \text { cal }}(\mathrm{mg} / \mathrm{g})$ & 2.010 & 3.887 & 6.165 & 7.711 & 9.709 & 11.299 \\
\hline & & $\mathrm{R}^{2}$ & 0.9952 & 0.9959 & 0.9958 & 0.9915 & 0.9923 & 0.9965 \\
\hline \multirow{9}{*}{$\begin{array}{c}\text { IPD } \\
\text { kinetic } \\
\text { model }\end{array}$} & \multirow{3}{*}{298} & $\mathrm{k}_{\mathrm{ipd}}\left(\mathrm{mg} / \mathrm{g} \cdot \min ^{0.5}\right)$ & 0.0825 & 0.1681 & 0.2167 & 0.2788 & 0.3533 & 0.4747 \\
\hline & & $\mathrm{C}(\mathrm{mg} / \mathrm{g})$ & 0.3164 & 0.6756 & 1.8343 & 2.6997 & 2.9587 & 3.2733 \\
\hline & & $\mathrm{R}^{2}$ & 0.9326 & 0.9273 & 0.7231 & 0.7218 & 0.7725 & 0.8147 \\
\hline & \multirow{3}{*}{308} & $\mathrm{k}_{\mathrm{ipd}}\left(\mathrm{mg} / \mathrm{g} \cdot \min ^{0.5}\right)$ & 0.1015 & 0.2299 & 0.3004 & 0.3533 & 0.4786 & 0.5983 \\
\hline & & $\mathrm{C}(\mathrm{mg} / \mathrm{g})$ & 0.2217 & 0.3892 & 1.1801 & 2.2021 & 2.8702 & 3.1965 \\
\hline & & $\mathrm{R}^{2}$ & 0.9497 & 0.9577 & 0.8519 & 0.8298 & 0.9053 & 0.8805 \\
\hline & \multirow{3}{*}{323} & $\mathrm{k}_{\mathrm{ipd}}\left(\mathrm{mg} / \mathrm{g} \cdot \mathrm{min}^{0.5}\right)$ & 0.1016 & 0.1985 & 0.3199 & 0.3391 & 0.4944 & 0.5606 \\
\hline & & $\mathrm{C}(\mathrm{mg} / \mathrm{g})$ & 0.5385 & 1.1052 & 1.7043 & 2.1541 & 3.0591 & 3.7434 \\
\hline & & $\mathrm{R}^{2}$ & 0.8872 & 0.8701 & 0.8629 & 0.7453 & 0.8247 & 0.8217 \\
\hline
\end{tabular}




\section{Conclusion}

In this work, MB adsorption on ALP was examined at various experimental conditions. The data obtained showed that adsorption of MB on ALP augmented with the rise in initial $\mathrm{MB}$ concentration, contact time and temperature. As the initial MB concentration changed from 10 to $60 \mathrm{mg} / \mathrm{L}, \mathrm{MB}$ adsorption capacity on ALP enlarged from 1.46 to $9.24 \mathrm{mg} / \mathrm{g}, 1.61$ to $9.71 \mathrm{mg} / \mathrm{g}$ and 1.89 to $10.71 \mathrm{mg} / \mathrm{g}$ for $298 \mathrm{~K}, 308 \mathrm{~K}$ and $323 \mathrm{~K}$, respectively. The equilibrium time for $\mathrm{MB}$ removal with ALP was determined at $120 \mathrm{~min}$.

Isotherm studies showed that Freundlich model was more suitable for MB adsorption on ALP than Langmuir and Temkin models. Parameters of all three isotherm models increased when temperature increased. In addition, it was determined that adsorption was positively affected by higher temperatures. The $\mathrm{R}^{2}$ values of the Freundlich model for MB removal with ALP were higher than those of the other two model. $\mathrm{q}_{\mathrm{m}}$ values of ALP were found to be $50.25,98.04,125.01 \mathrm{mg} / \mathrm{g}$ for $298 \mathrm{~K}, 308 \mathrm{~K}$ and 323 $\mathrm{K}$, respectively. This result indicates that adsorption process is of an endothermic nature.

Kinetic studies showed that process of MB adsorption was best suited to PSO model and suggested that the step of rate-limiting could be the dye chemisorption. The $\mathrm{R}^{2}$ coefficients were higher than 0.99 with the experimental and evaluated $\mathrm{q}_{\mathrm{e}}$ values very close to each other. The kinetic constants were closer to both temperatures and concentrations, while the qe values increased with the increase in $\mathrm{MB}$ concentration. Furthermore, IPD constant $\left(\mathrm{k}_{\mathrm{ipd}}\right)$ and monolayer concentration $(\mathrm{C})$ values increased with the upturn in temperature.

Thermodynamic parameters determined that MB adsorption on ALP occurred as an endothermic reaction. The negative $\Delta \mathrm{G}^{\circ}$ values indicated that adsorption was physisorption, while the $\Delta \mathrm{G}^{\circ}$ values suggested that adsorption was feasible and spontaneous. The absolute values of $\Delta \mathrm{G}^{\circ}$ decreased with the increase in temperature, which shows that this separation process is constructive at low temperatures. The positive values of $\Delta \mathrm{H}^{\circ}$ and $\Delta \mathrm{S}^{\circ}$ demonstrated that adsorption process was endothermic and affinity of ALP for MB. The results of the experiments clearly determined that ALP is an efficient adsorbent for the removal of $\mathrm{MB}$ from aqueous solution. In conclusion, ALP can be used as a prospective adsorbent for the removal of dyes in wastewaters.

\section{Acknowledgment}

The authors thanks to Van Yüzüncü Y1l University, Scientific Research Projects Commission (YYÜ BAP) for the financial support of this research under the FAP-2019-8615 grant number.

\section{Conflicts of interest}

The authors state that did not have conflict of interests.

\section{References}

[1]Peydayesh M., Rahbar-Kelishami A., Adsorption of methylene blue onto platanus orientalis leaf powder: kinetic, equilibrium and thermodynamic studies, J. Ind. Eng. Chem., 21 (2015) 1014-1019.

[2] Weng C. H., Lin Y. T., Tzeng T. W., Removal of methylene blue from aqueous solution by adsorption onto pineapple leaf powder, J. Hazard. Mater., 170(1) (2009) 417-424.

[3] Kallel F., Chaari F., Bouaziz F., Bettaieb F., Ghorbel R., Chaabouni S. E., Sorption and desorption characteristics for the removal of a toxic dye, methylene blue from aqueous solution by a low cost agricultural by-product, J. Mol. Liq., 219 (2016) 279-288.

[4] Gupta V. K., Suhas., Application of low-cost adsorbents for dye removal, a review, J. Environ. Manage., 90 (2009) 2313-2342.

[5] Yagub M. T., Sen T. K., Afroze S., Ang H. M., Dye and its removal from aqueous solution by adsorption, a review, Adv. Colloid Interface Sci., 209 (2014) 172-184.

[6] Forgacs E., Cserhati T., Oros G., Removal of synthetic dyes from wastewaters, a review, Env. Int., 30 (2004) 953-971.

[7] Zhou Y., Lu J., Zhou Y., Liu Y., Recent advances for dyes removal using novel adsorbents, a review, Env. Poll., 252 (2019) 352-365.

[8]Bouaziz F., Koubaa M., Kallel F., Chaari F., Driss D., Ghorbel R. E., Chaabouni S. E., Efficiency of almond gum as a low-cost adsorbent for methylene blue dye removal from aqueous solutions, Ind. Crops and Products, 74 (2015) 903-911.

[9] Kausar A., Iqbal M., Javeda A., Aftab K., Nazli Z. H., Bhatti H. N., Nouren S., Adsorption using clay and modified clay, a review, J. Mol. Liq., 256 (2018) 395-407.

[10] Mahmoodi N. M., Hayati B., Arami M., Lan C., Adsorption of textile dyes on pine cone from colored wastewater: kinetic, equilibrium and thermodynamic studies, Desalination, 268(1-3) (2011) 117-125.

[11] Debnath S., Ballav N., Maity A., Pillay K., Competitive adsorption of ternary dye mixture using pine cone powder modified with $\beta$ cyclodextrin, J. Mol. Liq., 225 (2017) 679-688. 
[12] Miyah Y., Lahrichi A., Idrissi M., Khalil A., Zerrouq F., Adsorption of methylene blue dye from aqueous solutions onto walnut shells powder: Equilibrium and kinetic studies, Surfaces and Interfaces, 11 (2018) 74-81.

[13] Singh N. B., Nagpal G., Agrawal S., Rachna., Water purification by using adsorbents, a review, Env. Tech. \& Innov., 11 (2018) 187-240.

[14] Jin Y., Zeng C., Lü Q-F, Yu Y., Efficient adsorption of methylene blue and lead ions in aqueous solutions by 5 -sulfosalicylic acid modified lignin, Int. J. Biol. Macromol., 123 (2019) 50-58.

[15] De Gisi S., Lofrano G., Grassi M., Notarnicola M., Characteristics and adsorption capacities of lowcost sorbents for wastewater treatment, a review, Sust. Materials Tech., 9 (2016) 10-40.

[16] Değermenci G. D., Değermenci N., Ayvaoğlu V., Durmaz E., Çakır D., Akan E., Adsorption of reactive dyes on lignocellulosic waste; characterization, equilibrium, kinetic and thermodynamic studies, J. Clean. Prod., 225 (2019) 1220-1229.

[17] Bouaziz F., Koubaa M., Kallel F., Ghorbel R. E., Chaabouni S. E. Adsorptive removal of malachite green from aqueous solutions by almond gum: kinetic study and equilibrium isotherms, Int. J. Biol. Macromol., 105(1) (2017) 56-65.

[18] Adegoke K. A., Bello, O. S., Dye sequestration using agricultural wastes as adsorbents, Water Resour. Ind., 12 (2015) 8-24.

[19] Bulgariu L., Escudero L. B., Bello O. S., Iqbal M., Nisar J., Adegoke K. A., Alakhras F., Kornaros M., Anastopoulos I., The utilization of leaf-based adsorbents for dyes removal, a review, J. Mol. Liq, 276 (2019) 728-747.

[20] Bedin K. C., Martins A. C., Cazetta A. L., Pezoti O., Almeida V. C., KOH-activated carbon prepared from sucrose spherical carbon: adsorption equilibrium, kinetic and thermodynamic studies for methylene blue removal, Chem. Eng. J., 286 (2016) 476-484.

[21] Hamed M. M., Ahmed I. M., Metwally S. S., Adsorptive removal of methylene blue as organic pollutant by marble dust as eco-friendly sorbent, J. Ind. Eng. Chem., 20(4) (2014) 2370-2377.

[22] Liu T., Li Y., Du Q., Sun J., Jiao Y., Yang G., Wang Z., Xia Y., Zhang W., Wang K., Zhu H., $\mathrm{Wu}$ D., Adsorption of methylene blue from aqueous solution by graphene, Colloids Surf. B Bio., 90 (2012) 197-203.

[23] Ojha A. K., Bulasara V. K., Adsorption characteristics of jackfruit leaf powder for the removal of Amido black 10B dye, Env. Prog. \& Sust. Energy, 34(2) (2015) 461-470.

[24] Han X., Wang W., Ma X., Adsorption characteristics of methylene blue onto low cost biomass material lotus leaf, Chem. Eng. J., 171(1) (2011) 1-8.

[25] Gouamid M., Ouahrani M. R., Bensaci M. B., Adsorption equilibrium, kinetics and thermodynamics of methylene blue from aqueous solutions using date palm leaves, Enrgy. Proced., 36 (2013) 898-907.

[26] Setiabudi H. D., Jusoh R., Suhaimi S. F. R. M., Masrur S. F., Adsorption of methylene blue onto oil palm (Elaeis guineensis) leaves: process optimization, isotherm, kinetics and thermodynamic studies, J. Taiwan Inst. of Chem. Eng., 63 (2016) 363-370.

[27] Bhattacharyya K., Sharma A., Kinetics and thermodynamics of methylene blue adsorption on neem leaf powder, Dyes and Pigments, 65(1) (2005) 51-59.

[28] Franca A. S., Oliveira L. S., Ferreira M. E., Kinetics and equilibrium studies of methylene blue adsorption by spent coffee grounds, Desalination, 249(1) (2009) 267-272.

[29] Rangabhashiyam S., Anu N., Nandagopal M. S. G., Selvaraju N., Relevance of isotherm models in biosorption of pollutants by agricultural by products, J. Env. Chem. Eng., 2(1) (2014) 398414.

[30] Khodabandehloo A., Rahbar-Kelishami A., Shayesteh H., Methylene blue removal using salix babylonica (weeping willow) leaves powder as a low-cost biosorbent in batch mode: Kinetic, equilibrium, and thermodynamic studies, J. Mol. Liq. 244 (2017) 540-548.

[31] Rida K., Bouraoui S., Hadnine S., Adsorption of methylene blue from aqueous solution by kaolin and zeolite, App. Clay. Sci., 83 (2013) 99-105.

[32] Rafatullah M., Sulaiman O., Hashim R., Ahmad A., Adsorption of methylene blue on low-cost adsorbents, a review, J. Hazard. Mater., 177(1-3) (2010) 70-80.

[33] Ponnusami V., Gunasekar V., Srivastava S. N., Kinetics of methylene blue removal from aqueous solution using gulmohar (Delonix regia) plant leaf powder: Multivariate regression analysis, $J$. Hazard. Mater., 169 (2009) 119-127.

[34] Kul A., Koyuncu H., Adsorption of $\mathrm{Pb}$ (II) ions from aqueous solution by native and activated bentonite: Kinetic, equilibrium and thermodynamic study, J. Hazard. Mater., 179 (2010) 332-339. 